УДК 556.532:502.7

DOI 10.33082/2226-1915 -2-2019-199-213

\title{
ОЦІНЮВАННЯ СТАНУ ПОВЕРХНЕВИХ ВОД ПІВНІЧНО-ЗАХІДНОГО ПРИЧОРНОМОР'Я ЗА ВМІСТОМ СИНТЕТИЧНИХ ПОВЕРХНЕВО-АКТИВНИХ РЕЧОВИН
}

\author{
А.П. Блажко \\ доцент кафедри «Гідротехнічне будівництво» \\ blazhko49@gmail.com
}

Одеська державна академія будівництва та архітектури

Анотація. У статті виконано екологічне оцінювання стану поверхневих вод Північно-Західного Причорномор'я в межах Одеської області (басейни річок Алкалія, Каплань, Хаджидер, Чага, Когильник, Сарата) за середньорічним та максимальним вмістом синтетичних поверхнево-активних речовин впродовж 2012-2017 рр. Дослідженням встановлено, що вміст СПАР в річкових водах перевищував граничнодопустимі конщентращії. 3'ясовано, що практично усі поверхневі води за вмістом СПАР відповідають IV та V класам, 6-7 категоріям якості, тобто води за якістю «дуже погані», а за ступенем чистоти - «дуже забруднені».

Ключові слова: поверхневі води, хімічний склад, якість поверхневих вод.

УДК 556.532:502.7

DOI 10.33082/2226-1915.1(58).2019.199-213

\section{ОЦЕНИВАНИЕ СОСТОЯНИЯ ПОВЕРХНОСТНЫХ ВОД СЕВЕРО-ЗАПАДНОГО ПРИЧЕРНОМОРЬЯ ПО СОДЕРЖАНИЮ СИНТЕТИЧЕСКИХ ПОВЕРХНОСТНО-АКТИВНЫХ ВЕЩЕСТВ}

А.П. Блажко

доцент кафедры «Гидротехническое строительство» blazhko49@gmail.com

Одесская государственная академия строительства и архитектуры

Аннотация. В статье выполнено экологическое оиенивание состояния поверхностных вод Северо-Западного Причерноморья в гранииах Одесской области (бассейны рек Алкалия, Каплань, Хаджидер, Чага, Когильник, Сарата) по содержанию синтетических поверхностноактивных вешеств за 2012-2017 г2. Исследованием установлено, что содержание СПАВ в речных водах превышало предельно-допустимые значения.

(C) Блажко А.П., 2019 
Выяснено, что практически все поверхностные воды по содержанию СПАВ соответствуют IV и $V$ классам, 6-7 категориям качества, т.е. воды по качеству «очень плохие», а по степени чистоты - «очень грязные».

Ключевые слова: поверхностные воды, химический состав, качество поверхностных вод.

UDC 556.532:502.7

DOI 10.33082/2226-1915-1-2019-199-213

\title{
ASSESSMENT OF THE SURFACE WATER OF THE NORTH-WEST BLACK SEA WITHIN THE SYNTHETIC CONTENT OF SURFACE-ACTIVE SUBSTANCES
}

\author{
A.P. Blazhko \\ Associate Professor of the Department «Hydraulic Engineering» \\ Odessa State Academy of Civil Engineering and Architecture
}

\begin{abstract}
The ecological assessment of the surface waters of the NorthWestern Black Sea region within the Odessa region (basins of the Alkali, Kaplan, Hadzhider, Chaga, Kogylnyk, Sarata Rivers by the average and maximum content of synthetic surface-active agents is made in the article.

The results of observations of the Separate subdivision of the Basin Water Resources Management Department of the Black Sea and lower Danube Black Sea Water Resources Center (subject of environmental monitoring in Odessa region) are used on water objects for 2012-2017, provided by the Ecology Department and natural resources of the Odessa regional state administration. By the research has been found that the content of synthetic surface-active agents in river waters exceeded the maximum permissible concentrations for fisheries waters, which makes it impossible to use surface waters of the research area for the fisheries sector. The highest concentrations of toxicological pollutant in river waters were observed in 2017, the excess of maximum-rated concentration for the average and maximal amounts has made in accordance with: Kaplan River (4,95 / 6,35 times); Hadger River (4,95/6,35 times); Chaga River (2,40/2,95 times); Kogilnyk River (2,10/3,10 times), Sarata River (1,85/2,20 times). According to the results of the environmental assessment, practically all surface waters according to the SPAR content correspond to the IV and V classes, 6-7 quality categories, that is, the water qua-lity is «very bad» and the degree of purity is «very polluted».
\end{abstract}

Keywords: surface waters, chemical formula, the quality of surface waters.

Вступ. Синтетичні поверхнево-активні речовини (СПАР) широко розповсюджена група забруднювачів навколишнього природного середовища. Завдяки своїм фізико-хімічним властивостям СПАР знаходять за- 
стосування в усіх галузях промисловості, сільського господарства, транспорту та використовуються під час вирішення екологічних проблем [1].

Основним джерелом надходження СПАР у водні об'єкти $є$ неочищені і недостатньо очищені господарсько-побутові та промислові стічні води. Потрапляючи до водойм чи водотоків СПАР негативно впливають на їх фізико-біологічний стан, значно погіршуючи кисневий режим $\mathrm{i}$ органолептичні властивості, які визначають за допомогою органів чуття смаку, запаху тощо, і зберігаються там протягом тривалого часу, оскільки розчиняються повільно. Головними факторами зниження їх концентрації $\epsilon$ процеси біохімічного окиснення, сорбція завислими речовинами $\mathrm{i}$ донними відкладами.

Викиди промислових стічних вод, забруднених поверхневоактивними речовинами (ПАР), які складають значну частину токсичних витоків, призвели до критичного стану поверхневих джерел води в Україні, що формувався протягом тривалого періоду через нехтування об'єктивними законами розвитку і відтворення природно-ресурсного комплексу України [2]. Потрапляючи у водойми, найбільш розповсюджені синтетичні поверхнево-активні речовини перешкоджають процесам біологічного окиснення і запобігають їхньому самоочищенню. В результаті погіршуються санітарно-хімічні показники якості води: збільшується сухий залишок, зростає споживання кисню. Крім того, вода набуває неприємного присмаку та запаху, якщо в ній присутні синтетичні поверхнево-активні речовини.

Мета дослідження, постановка задачі. Мета роботи - проаналізувати наукові літературні дані щодо впливу синтетичних поверхнево-активних речовин на різноманітні функції клітин і організму в цілому, дослідити ступінь забруднення поверхневих вод ПівнічноЗахідного Причорномор'я за середньорічними і максимальними значеннями СПАР.

Матеріали досліджень. У роботі використані результати гідрохімічних спостережень за якістю води в річках Алкалія (с. Широке), Каплань (с. Крутоярівка), Хаджидер (с. Чистоводне), р. Чага (с. Петрівка), p. Когильник (с. Новоолексіївка), р. Сарата (с. Білолісся) за 2012-2017 роки, які надані Департаментом екології та природних ресурсів Одеської обласної державної адміністрації [3]. Проби води відбирались і досліджувалися лабораторією Відокремленого підрозділу Басейнового управління водних ресурсів річок Причорномор'я та нижнього Дунаю «Причорноморський центр водних ресурсів» (суб'єкт екологічного моніторингу в Одеській області) щоквартально чотири рази на рік. Організація спостережень за якістю річкових вод, а також перелік контрольованих гідрохімічних показників відповідають нормативному документу «Є дине міжвідомче керівництво по організації та здійсненню державного моніторингу вод» [4]. 
Аналіз джерел і публікацій за темою дослідження. Провівши аналіз наукових публікацій за темою дослідження з'ясовано, що найбільш досліджено вплив СПАР та синтетичних миючих засобів на їх основі, на здоров'я працюючих в умовах виробництва. Негативний вплив СПАР на якість довкілля виявлено тільки в 60-і роки минулого століття. У зв 'язку з цим почалися інтенсивні дослідження токсикологічних властивостей поверхнево-активних речовин, як поширених забруднювачів поверхневих вод $[5 ; 6]$.

Основними центрами токсиколого-гігієнічних досліджень СПАР, як сировини для виробництва синтетичних мийних та чистячих засобів, стали Київський НДІ загальної і комунальної гігієни ім. О.М. Марзеєва МОЗ УРСР (м. Київ), Всесоюзний НДІ токсикології пестицидів, полімерних і пластичних матеріалів МОЗ СРСР (м.Київ), Інститут загальної і комунальної гігієни ім. О.М. Сисіна АМН СРСР (м. Москва), Ростовський медичний інститут, Чернівецький, Донецький, Вінницький, Харківський та Дніпропетровський медичні інститути, Інститут харчової хімії i технології та Інститут фізіології ім. О.О. Богомольця АН УРСР (м.Київ).

За два десятиліття (1970-1990рр.) зазначеними установами та зарубіжними дослідниками були проведені грунтовні токсикологогігієнічні дослідження СПАР при різних шляхах надходження в організм лабораторних тварин, вивчено вплив їх на здоров`я працюючих та населення, що мешкало за межами санітарно захисних зон промислових підприємств побутової хімії, а також були розроблені кілька десятків гігієнічних нормативів детергентів в об єктах навколишнього середовища (поверхневих та грунтових водах, повітрі робочої зони та атмосферному повітрі населених місць).

Поверхнево-активні речовини являються емульгаторами 3 особливими властивостями, які дозволяють з'єднувати воду і жири так, що утворюються повітряні бульбашки - піна [7]. ПАР - це речовини, що змінюють поверхневий натяг рідин, жирів. В миючих та пральних засобах використовуються 3 метою покращення миючих властивостей.

СПАР або детергенти виробляються в основному з нафти, вугілля, сланців і природного газу і $\epsilon$ основною сировиною для виробництва синтетичних миючих засобів (СМЗ). У водні об'єкти СПАР потрапляють у значних кількостях 3 господарсько-побутовими та промисловими стічними водами. Потрапляючи у водойми, СПАР можуть впливати на їх фізико-хімічний стан, погіршуючи кисневий режим та органолептичні властивості. Разом з тим, СПАР довгий час зберігаються у водах річок та повільно розкладаються [7].

Синтетичні ПАР відносяться, в основному, до 3-го та 4-го класу небезпеки, тобто $\epsilon$ помірно- та малотоксичними речовинами та чинять подразнюючу дію на шкіру та слизову оболонку органів дихання й очей. Остання властивість особливо характерна для порошковидних (сипучих) 
CM3, основними компонентами яких є детергенти [8]. Основні діючі компоненти пральних порошків - поверхнево-активні речовини. Ці активні хімічні сполуки, потрапляючи в організм, руйнують живі клітини шляхом порушення найважливіших біохімічних процесів.

Залежно від властивостей, які проявляються СПАР при розчиненні у воді, їх поділяють на аніоноактивні речовини (активною частиною $\epsilon$ аніон), катіоноактивні (активною частиною молекул є катіон), амфолітні і неіоногенні, які зовсім не іонізуються. Основні діючі компоненти пральних порошків - поверхнево-активні речовини. Ці активні хімічні сполуки, потрапляючи в організм, руйнують живі клітини шляхом порушення найважливіших біохімічних процесів.

В експериментах на тваринах учені встановили, що СПАР істотно змінюють інтенсивність окислювально-відновних реакцій, впливають на активність ряду найважливіших ферментів, порушують білковий, вуглеводний і жировий обмін. Особливо агресивні у своїх діях аніонні ПАР. Вони здатні викликати грубі порушення імунітету, розвиток алергії, ураження мозку, печінки, нирок, легенів [8].

СПАР в відповідних ситуаціях являються більш небезпечними забруднювачами оточуючого середовища, ніж уважали раніше. Попадання синтетичних поверхнево-активних речовин в оточуюче середовище значуще і продовжує щорічно наростати (в залежності від класу СПАР), приблизно на $2-5 \%$ [8].

Чутливість до отрут у риб сильно варіює залежно від видових, вікових, індивідуальних особливостей і фізіологічного стану їх організму. Високочутливими до токсикантам є лососеві (веселкова форель, лосось), судак, окунь; слабо вразливі - короп, карась, лінь, в'юн. Інші риби займають проміжне між ними положення. В протилежність людині і вищим тваринам в організм риб більшість отруйних речовин проникають осмотичним шляхом - через зябра і шкіру, особливо пошкоджену. У риб гострі отруєння різними детергентами проявляються приблизно однаково. При високих концентраціях СПАР спостерігається сильне занепокоєння або, навпаки, пригнічення риб, порушується координація руху, реакції на зов-нішні подразники пригнічені, тулуб рясно покривається слизом, відзна-чаються типові симптоми задухи. У загиблих риб зяброві кришки широко розкриті, хвостове стебло іноді загнуте вгору.

Попри те, що є велика кількість робіт, присвячених вивченню різних аспектів дії СПАР на якість води, процеси самоочищення водойм, організм людини і тварин, дія цих речовин доки вивчена недостатньо. Це пов'язано з тим, що щорічно синтезуються не лише окремі нові СПАР, але і цілі групи і класи з'єднань, які знаходять широке застосування у багатьох галузях народного господарства.

Вчені $[9 ; 10]$ дійшли до висновку, що подразнюючі концентрації вмісту аерозолей синтетичних поверхнево-активних речовин у повітрі 
може стати причиною появи локальних некрозів, погіршення еластичності легенів, порушення транспорту кисню через аерогематичний бар'єр. Це може призвести до гемодинамічних зрушень та появи перших ознак гіпоксії При цьому може спостерігатись порушення функції зовнішнього дихання. Нові синтезовані детергенти також впливають на імунний статус організму. Доведено, що лапроксиди при тривалому пероральному надходженні в організм порушують імунну відповідь, при цьому спостерігається зниження титрів імунних антитіл, зміни рівня альбумінів та імуноглобулінів різних класів в сироватці крові. Тривала дія поверхневоактивних речовин приводить до розвитку вторинного імунодефіциту в організмі тварин [11].

Результати досліджень та їх обговорення. Результати фактичних досліджень вмісту СПАР в поверхневих водах річкових басейнів Північно-Західного Причорномор'я за середньорічними та максимальними значеннями наведено в таблиці 1 .

Таблиия 1

Середньорічні та максимальні значення вмісту СПАР в водних об'єктах Північно-Західного Причорномор'я за 2012-2017 роки

\begin{tabular}{|c|c|c|c|c|c|c|c|c|c|c|c|c|}
\hline \multirow{3}{*}{$\begin{array}{l}\text { Водний } \\
\text { об’єкт } \\
\text { (річка) }\end{array}$} & \multicolumn{12}{|c|}{$\begin{array}{c}\text { Середньорічний та максимальний вміст СПАР в річкових } \\
\text { водах, } \mathrm{мг} / \text { дм }^{3}\end{array}$} \\
\hline & \multicolumn{2}{|c|}{2012} & \multicolumn{2}{|c|}{2013} & \multicolumn{2}{|c|}{2014} & \multicolumn{2}{|c|}{2015} & \multicolumn{2}{|c|}{2016} & \multicolumn{2}{|c|}{2017} \\
\hline & ep & & & & $\mathrm{p}$ & & $\mathrm{p}$ & & ep & мак & ep & \\
\hline & & & & & & & 70 & & 31 & & 4 & \\
\hline $\mathrm{Ka}$ & 9 & & 3 & 3 & 0,33 & 0.48 & 99 & 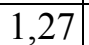 & 36 & 4 & 53 & \\
\hline $\begin{array}{l}\text { Хад〉 } \\
\text { дер }\end{array}$ & 017 & & & (1) & $\begin{array}{lll}0 & 21\end{array}$ & ( & 0,99 & 1,27 & 0,27 & ? & 0,28 & \\
\hline Чага & 37 & & & $0, i 3$ & & & $0,+0$ & & 0,33 & & $0,+0$ & 0,00 \\
\hline $\begin{array}{l}\text { Когиль- } \\
\text { ник }\end{array}$ & 0,37 & 0,66 & 0 & 0 , & 0,43 & 0,57 & 0,42 & 0,62 & 0,5 & 1 & 0,78 & 1,39 \\
\hline Сарата & 0,45 & 0,56 & 0,58 & 1,37 & 0,27 & 0,42 & 0,37 & 0,44 & 0,45 & 0,78 & 0,72 & 1,09 \\
\hline
\end{tabular}

За результатами спостережень, які поміщено в таблиці 1, можливо стверджувати наступне.

Перш за все в поверхневих водах річок Алкалія, Каплань, Хаджидер, Когильник, Сарата намітилася тенденція щодо зростання вмісту синтетичних поверхнево-активних речовин. Так, наприклад, в річковій воді Алкалії вміст зазначеного токсичного забруднювача збільшився за середньорічними показниками $30,28 \mathrm{мг} /$ дм $^{3}$ (2012 р.) до $0,54 \mathrm{мг} /$ дм $^{3}$ (2017 р.), а за максимальними від 0,52 мг/дм ${ }^{3}$ (2012 р.) до 0,82 мг/дм ${ }^{3}$ (2017 p.), в річці Каплань - від 0,29 до 0,53 мг/дм ${ }^{3}$ та 30,52 до 0,75 мг/дм ${ }^{3}$ відповідно, а в поверхневих водах Когильника концентрація 
СПАР впродовж досліджуваного періоду зросла від 0,37 до 0,78 мг/дм ${ }^{3}$ (за середньорічними значеннями) і від 0,66 до 1,39 мг/дм ${ }^{3}$ (за максимальними значеннями).

Динаміка вмісту синтетичних поверхнево-активних речовин в басейнах річок Північно-Західного Причорномор'я проілюстрована на рисунку 1.

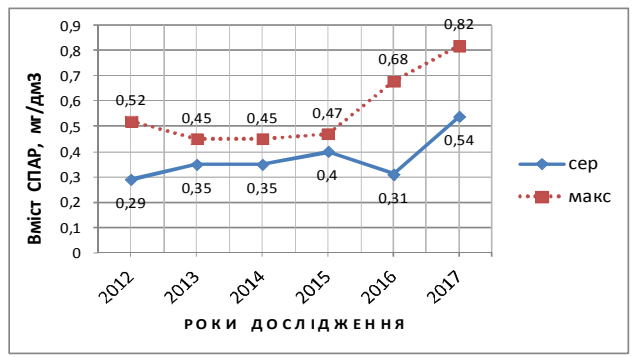

Басейн р. Алкалія

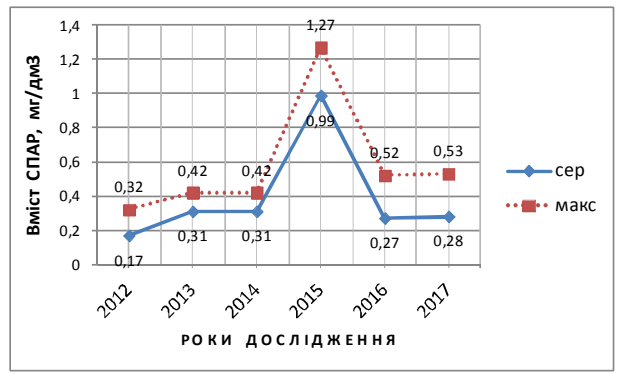

Басейн р. Хаджидер

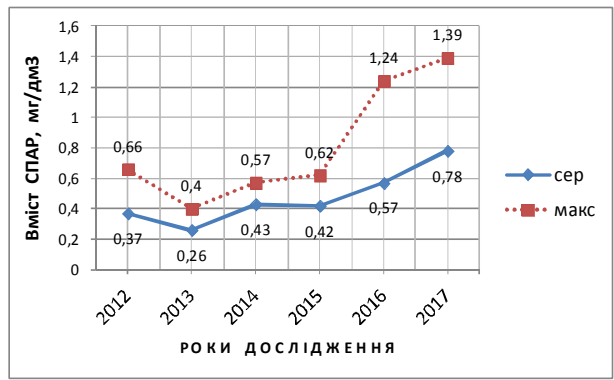

Басейн р. Когильник

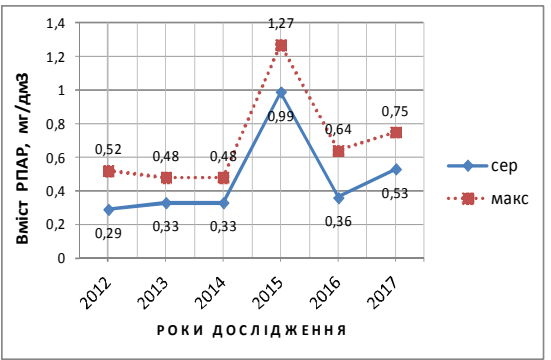

Басейн р. Каплань

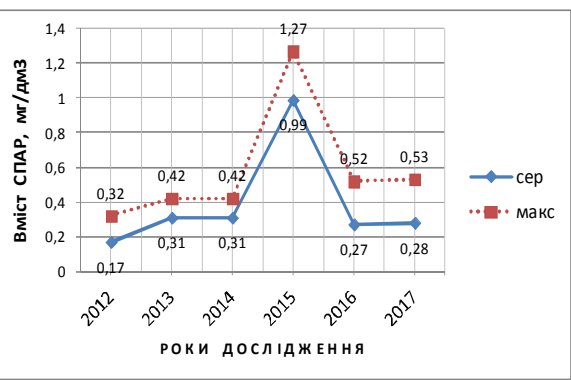

Басейн р. Чага

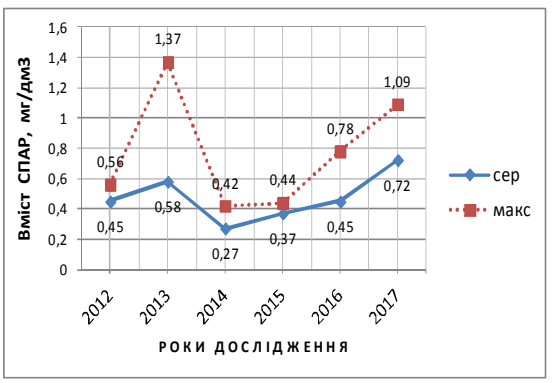

Басейн р. Сарата

Рис. 1. Динаміка вмісту СПАР за середньорічними та максимальними значеннями в поверхневих водах Північно-Західного Причорномор'я 
Межі коливань середньорічних значень показників СПАР в поверхневих водах за період дослідження складають: р. Алкалія $(0,29-$ 0,54 мг/дм ${ }^{3}$, амплітуда $-0,25$ мг/дм $\left.{ }^{3}\right)$, р. Каплань $\left(0,29-0,99\right.$ мг/дм ${ }^{3}$, амплітуда $-0,70$ мг/дм $\left.{ }^{3}\right)$, p. Хаджидер $\left(0,17-0,99\right.$ мг/дм ${ }^{3}$, амплітуда 0,82 мг/дм $\left.{ }^{3}\right)$, р. Чага $\left(0,26-0,48\right.$ мг/дм ${ }^{3}$, амплітуда $-0,22 \mathrm{мг} /$ дм $\left.^{3}\right)$, p. Когильник $\left(0,36-0,78\right.$ мг/дм ${ }^{3}$, амплітуда $-0,42$ мг/дм $\left.{ }^{3}\right)$, p. Сарата $(0,27-$ $0,72 \mathrm{мг} /$ дм $^{3}$, амплітуда $-0,46$ мг $/$ дм $\left.^{3}\right)$.

Тобто найбільша мінливість вмісту СПАР в річковій воді Хаджидер, а найменша - в р. Чага.

За максимальними значеннями в досліджуваному періоді амплітуда коливань вмісту СПАР змінювалася у межах: р. Алкалія $(0,45-0,82$ мг/дм $\left.{ }^{3}\right)$, p. Каплань $\left(0,48-1,27\right.$ мг/дм $\left.{ }^{3}\right)$, p. Хаджидер $\left(0,32-1,27\right.$ мг/дм $\left.{ }^{3}\right)$, p. Чага $\left(0,35-0,89\right.$ мг/дм $\left.{ }^{3}\right)$, p. Когильник $\left(0,40-1,39\right.$ мг/дм $\left.{ }^{3}\right)$, p. Сарата $(0,42-$ $1,37 \mathrm{мг} /$ дм $\left.^{3}\right)$.

Амплітуди коливань максимальних концентрацій СПАР в поверхневих водах досліджуваної території становили: р. Алкалія - амплітуда 0,37 мг/дм ${ }^{3}$; p. Чага $-0,54$ мг/дм ${ }^{3}$; p. Каплань $-0,79$ мг/дм ${ }^{3}$; p. Сарата -

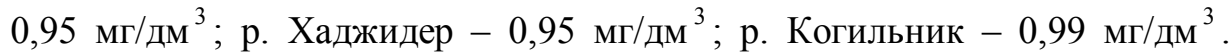
Отримані результати можливо проілюструвати графіками (рис. 2).

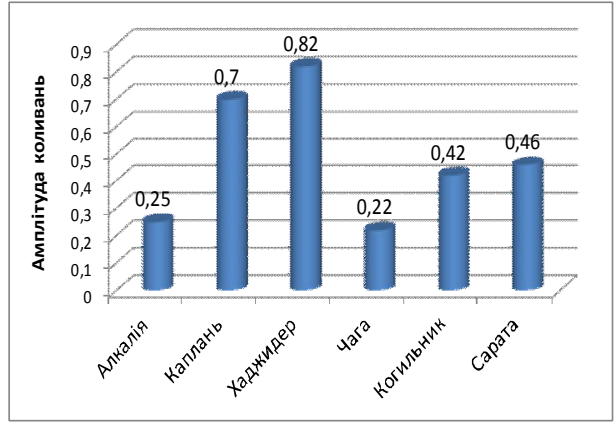

a)

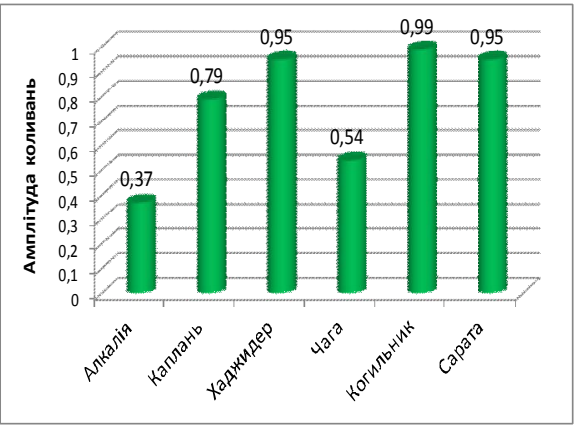

б)

Рис. 2. Динаміка амплітуди коливань вмісту СПАР в поверхневих водах Причорномор'я впродовж 2012-2017 рр.:

а) за середньорічними значеннями; б) за максимальними значеннями

Слід зазначити, що значне збільшення ступеня забруднення поверхневих вод досліджуваних водних об'єктів (як за середньорічними, так і за максимальними значеннями показників СПАР) спостерігалося впродовж 2016-2017 pр. У зв'язку з тим, що надходження СПАР у річкові води носить невпорядкований (стихійний) характер можливо 3 високою 
вірогідністю стверджувати, що процес забруднення річкових вод носить антропогенний характер пов'язаний з господарською діяльністю (скиди неочищених і недостатньо очищених господарсько-побутових та промислових стічних вод).

Ознакою репрезентативності показників якості води, як індикаторів забруднення, є рівень забруднення, в якості міри якого використовується широко розповсюджений в гідрохімічній практиці показник кратності перевищення граничнодопустимих концентрацій (ГДК). В даній роботі за нормовані показники прийнято граничнодопустимі значення для водойм рибогосподарського призначення [12].

Показники кратності перевищення фактичного вмісту СПАР відносно граничнодопустимих концентрацій як за середньорічними, так і за максимальними значе6ннями наведено в таблиці 2.

Таблиия 2

\section{Показники кратності перевищення фактичного вмісту СПАР по відношенню до ГДК \\ Північно-Західного Причорномор'я за 2012-2017 рр.}

\begin{tabular}{|c|c|c|c|c|c|c|c|c|c|c|c|c|}
\hline \multirow[t]{3}{*}{$\begin{array}{c}\text { Водний } \\
\text { об’єкт } \\
\text { (річка) }\end{array}$} & \multicolumn{12}{|c|}{$\begin{array}{c}\text { Кратність перевищення вмісту СПАР } \\
\text { по відношенню до ГДК } \\
\Pi \text { (рази) }\end{array}$} \\
\hline & \multicolumn{2}{|c|}{2012} & \multicolumn{2}{|c|}{2013} & \multicolumn{2}{|c|}{2014} & \multicolumn{2}{|c|}{2015} & \multicolumn{2}{|c|}{2016} & \multicolumn{2}{|c|}{2017} \\
\hline & cep & мак & cep & мак & cep & мак & cep & мак & cep & мак & cep & мак \\
\hline Алкалія & 1,45 & 2,60 & 1,75 & 2,25 & 1,75 & 2,25 & 2,00 & 2,35 & 1,55 & 3,40 & 2,70 & 4,10 \\
\hline Каплань & 1,45 & 2,60 & 1,65 & 2,40 & 1,65 & 2,40 & 4,95 & 6,35 & 1,80 & 3,20 & 2,65 & 3,75 \\
\hline $\begin{array}{l}\text { Хаджи } \\
\text { дер }\end{array}$ & 0,85 & 1,60 & 1,55 & 2,10 & 1,55 & 2,10 & 4,95 & 6,35 & 1,35 & 2,60 & 1,40 & 2,65 \\
\hline Чага & 1,85 & 4,45 & 1,95 & 3,95 & 1,30 & 1,75 & 2,40 & 2,95 & 1,65 & 2,70 & 2,30 & 3,00 \\
\hline $\begin{array}{l}\text { Когиль- } \\
\text { ник }\end{array}$ & 1,85 & 3,30 & 1,80 & 2,00 & 2,15 & 2,85 & 2,10 & 3,10 & 2,85 & 6,20 & 3,90 & 6,95 \\
\hline Сарата & 2,25 & 2,80 & 2,90 & 6,85 & 1,35 & 2,10 & 1,85 & 2,20 & 2,25 & 3,90 & 3,60 & 5,45 \\
\hline
\end{tabular}

Аналіз даних, викладених в таблиці, свідчить про те, що практично впродовж усього періоду спостереження вміст досліджуваного токсичного забруднювача в річкових водах перевищував граничнодопустимі концентрації для водойм рибогосподарського призначঊнйбільша кількість СПАР спостерігалася в поверхневих водах в 2015 та 2017 роках.

Так в 2015 році перевищення ГДК симальними значеннями становило відповідно: р. Алкалія $(2,00 / 2,35$ раз); p. Каплань $(2,65 / 3,75$ раз); р. Хаджидер $(1,40 / 2,65$ ра3); р. Чага $(2,30 / 3,00$ раз); р. Когильник $(3,90 / 6,95$ раз), р. Сарата $(3,60 / 5,45$ раз). 
Впродовж 2017 року, перевищення ГДК максимальними значеннями становило: р. Алкалія (2,70/4,10 раз); p. Каплань (4,95/6,35 раз); р. Хаджидер (4,95/6,35 раз); р. Чага $(2,40 / 2,95$ раз); р. Когильник $(2,10 / 3,10$ раз), р. Сарата $(1,85 / 2,20$ раз).

Звісно, що за вмістом СПАР такі поверхневі води не можуть бути використані для рибогосподарського призначення без попередньої їх меліорації.

Для наглядності наведемо динаміку зміни величин перевищення вмісту СПАР по відношенню до ГДК ваному періоді (рис. 3).

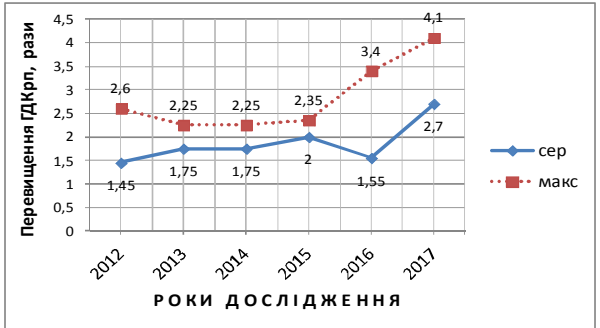

Басейн р. Алкалія

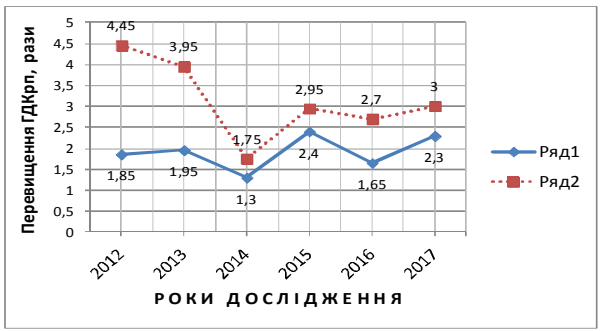

Басейн р. Хаджидер

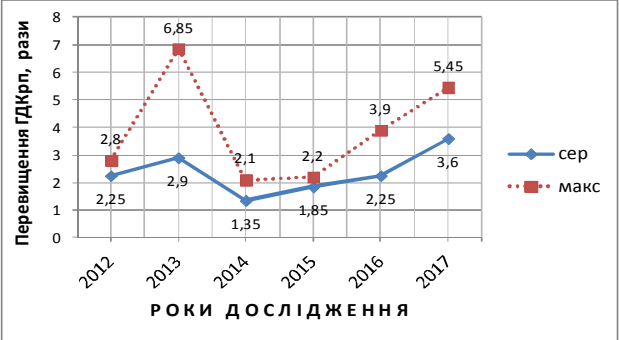

Басейн р. Когильник

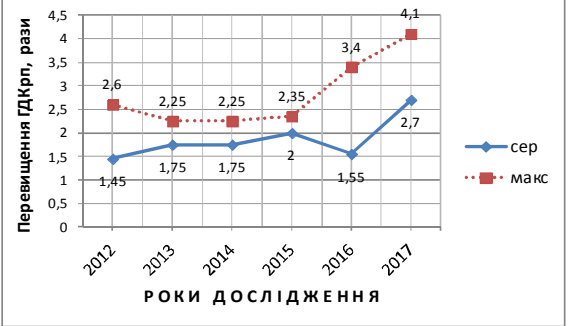

Басейн р. Каплань

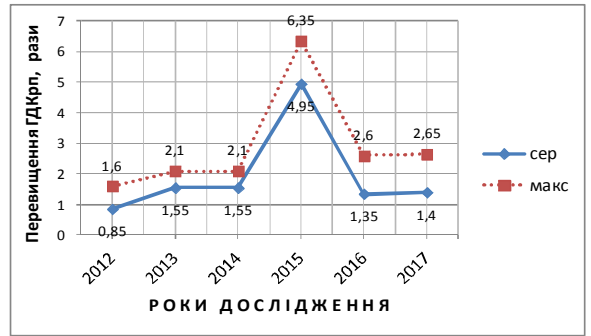

Басейн р. Чага

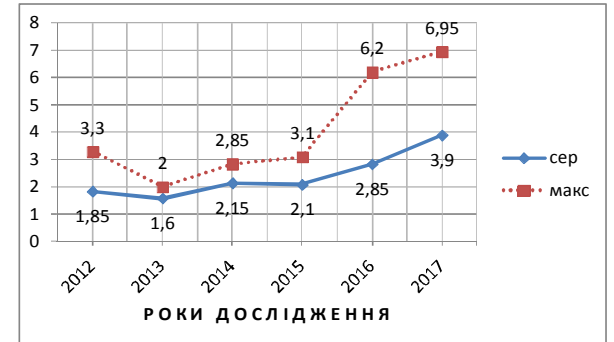

Басейн р. Сарата

Рис. 3. Динаміка перевищення вмісту СПАР по відношенню до ГДК РП в поверхневих водах Північно-Західного Причорномор'я 
ВІСНИК

ОДЕСЬКОГО НАЦІОНАЛЬНОГО

МОРСЬКОГО УНІВЕРСИТЕТУ

№ 2 (59), 2019
HERALD

OF THE ODESSA

NATIONAL MARITIME UNIVERSITY

Згідно з екологічною класифікацією якості вод суші, яка викладена в Методиці екологічної оцінки якості поверхневих вод за відповідними категоріями [13], СПАР відносяться до специфічних речовин токсичної дії.

Результати екологічного оцінювання якості річкових вод досліджуваної території за вмістом СПАР наведено в таблиці 3.

Таблиия 3

\section{Результати екологічного оцінювання якості поверхневих вод Північно-Західного Причорномор'я за вмістом СПАР [13]}

\begin{tabular}{|c|c|c|c|c|c|c|c|c|c|}
\hline \multirow{3}{*}{$\begin{array}{l}\text { Назва } \\
\text { водного } \\
\text { об'єкту }\end{array}$} & \multirow{3}{*}{$\begin{array}{c}\text { Роки } \\
\text { дослід- } \\
\text { ження }\end{array}$} & \multicolumn{8}{|c|}{$\begin{array}{l}\text { Оцінювання якості поверхневих вод за вмістом СПАР } \\
\text { (клас, категорія) }\end{array}$} \\
\hline & & \multicolumn{2}{|c|}{ I кв-Л } & \multicolumn{2}{|c|}{ II кв-Л } & \multicolumn{2}{|c|}{ III кв-Л } & \multicolumn{2}{|c|}{ IV кв-л } \\
\hline & & дата & якість & дата & якість & дата & якість & дата & якість \\
\hline \multirow[t]{5}{*}{ Алкалія } & 2012 & 22.03 & V-7 & 15.05 & V-7 & 13.08 & IV-6 & 21.11 & $\mathrm{~V}-7$ \\
\hline & 2013 & 28.03 & V-7 & 24.05 & V-7 & 26.07 & V-7 & 08.11 & $V-7$ \\
\hline & 2014 & 28.03 & V-7 & 24.05 & V-7 & 26.07 & IV-6 & 08.11 & $V-7$ \\
\hline & 2015 & 19.02 & V-7 & 14.05 & V-6 & сухо & сухо & сухо & V-7 \\
\hline & 2016 & 10.02 & V-7 & 19.05 & V-7 & 10.08 & IV-6 & 01.11 & V-7 \\
\hline \multirow[t]{5}{*}{ Каплань } & 2012 & 10.02 & V-7 & 16.05 & IV-6 & 10.08 & V -7 & 01.11 & V-7 \\
\hline & 2013 & 28.03 & $\mathrm{~V}-{ }^{-}$ & 24.05 & V-7 & 26.07 & IV-6 & 08.11 & V-7 \\
\hline & 2014 & 28.03 & V-7 & 24.05 & V-7 & 26.07 & IV-6 & 08.11 & V-7 \\
\hline & 2015 & 19.02 & V-7 & 14.05 & V-7 & 07.08 & V-7 & 23.10 & V-7 \\
\hline & 2016 & 10.02 & V-7 & 16.05 & $\mathrm{~V}-7$ & 10.08 & V-7 & 01.11 & V-7 \\
\hline \multirow{5}{*}{$\begin{array}{l}\text { Хаджи- } \\
\text { дер }\end{array}$} & 2012 & 22.03 & IV-6 & 15.05 & IV-6 & 13.08 & IV-6 & 21.11 & V-7 \\
\hline & 2013 & 28.03 & V-7 & 24.05 & V-7 & 26.07 & IV-6 & 08.11 & V-7 \\
\hline & 2014 & 28.03 & V-7 & 24.05 & V-7 & 26.07 & V-7 & 08.11 & V-7 \\
\hline & 2015 & 19.02 & V-7 & 14.05 & V-7 & 07.08 & V-7 & 23.10 & IV-6 \\
\hline & 2016 & 10.02 & V-7 & 16.05 & IV-6 & 10.08 & IV-6 & 01.11 & IV-6 \\
\hline \multirow[t]{5}{*}{ Чага } & 2012 & 21.03 & IV-6 & 15.05 & \begin{tabular}{|l|} 
IV-6 \\
\end{tabular} & 13.08 & V-7 & 21.11 & $\mathrm{~V}-7$ \\
\hline & 2013 & 29.03 & V-7 & 24.05 & V-7 & 26.07 & IV-6 & 08.11 & V-7 \\
\hline & 2014 & 28.03 & V-7 & 24.05 & V-7 & 26.07 & IV-6 & 08.11 & $V-7$ \\
\hline & 2015 & 19.02 & V-7 & 14.05 & V-7 & 07.08 & $V-7$ & 23.10 & $V-7$ \\
\hline & 2016 & 10.02 & V-7 & 16.05 & V-7 & 10.08 & V-7 & 01.11 & $V-7$ \\
\hline \multirow{5}{*}{$\begin{array}{l}\text { Когиль- } \\
\text { ник }\end{array}$} & 2012 & 23.03 & IV-6 & 15.05 & $\mathrm{~V}-7$ & 13.08 & V-7 & 21.11 & V-7 \\
\hline & 2013 & 29.03 & V-7 & 14.05 & V-7 & 26.07 & $V-7$ & 08.10 & V-7 \\
\hline & 2014 & 28.03 & V-7 & 24.05 & V-7 & 26.07 & V-7 & 08.11 & V-7 \\
\hline & 2015 & 19.02 & V-7 & 14.05 & V-7 & 07.08 & V-7 & 23.10 & V-7 \\
\hline & 2016 & 10.02 & V-7 & 16.05 & V-7 & 10.08 & IV-6 & 01.11 & V-7 \\
\hline \multirow[t]{5}{*}{ Сарата } & 2012 & 21.03 & V-7 & 15.05 & V-7 & 13.08 & V-7 & 21.11 & V-7 \\
\hline & 2013 & 28.03 & V-7 & 24.05 & V-7 & 26.07 & V-7 & 08.11 & V-7 \\
\hline & 2014 & 28.03 & V-7 & 24.05 & V-7 & 26.07 & V-7 & 08.11 & V-7 \\
\hline & 2015 & 05.02 & V-7 & 14.05 & V-7 & 07.08 & V-7 & 23.10 & V-7 \\
\hline & 2016 & 10.02 & V-7 & 16.05 & V-7 & 10.08 & IV-6 & 01.11 & V-7 \\
\hline
\end{tabular}


Слід зазначити, що аналіз табличного матеріалу дозволяє оцінювати якість поверхневих вод за вмістом СПАР як незадовільною.

Практично усі водні об'єкти досліджуваної території за вмістом СПАР відносяться до IV та V класів якості, 6-7 категорій. Звісно, води такої якості не можуть бути використані для будь-якого виду водокористування без попередньої водопідготовки (меліорації).

\section{Висновки}

1. Поверхневі води Північно-Західного Причорномор'я характеризуються високим рівнем антропогенного забруднення за вмістом синтетичних поверхнево-активних речовин.

2. Згідно до літературних наукових досліджень встановлено, що синтетичні поверхнево-активні речовини здатні викликати порушення найважливіших фізіологічних процесів, що протікають в організмі, змінюючи функцію і цілісність клітини.

3. Причиною надходження у водні об'єкти забруднюючих токсичних речовин є скиди неочищених або недостатньо очищених стічних господарсько-побутових та промислових стічних вод.

4. Високі концентрації СПАР унеможливлюе використання поверхневих вод Північно-Західного Причорномор'я для рибогосподарського водокористування без попередньої їх очистки.

5. Необхідність очистки річкових вод очевидна. Для ефективної очистки поверхневих вод від СПАР можливо застосовувати різні методи: хімічні, фізичні, біологічні, коагуляцію, випаровування, озонування тощо.

6. Високий рівень забруднення поверхневих вод досліджуваної території потребує продовження екологічного моніторингу.

\section{СПИСОК ЛІТЕРАТУРИ}

1. Хільчевський В.К. Основи гідрохімії [Текст]: підручник / В.К. Хільчевський, В.І. Осадчий, С.М. Курило. - К.: НікаЦентр, 2012. - 312 c., 24 c.

2. Хромитева О.О. Вилучення іоногенних поверхнево-активних речовин із водних розчинів методом осаджувальної та сорбиіийної мікрофлотаиії. НАНУ: автореф. дис. канд. хімічних наук: 02.00.11 / Хромишева Олена Олександрівна. Інститут біоколоїдної хімії ім.. Ф.Д. Овчаренка. К. 2008. - 29 с. [Електронний ресурс]. Режим достуnу: https://studfiles.net/ preview/8172177

3. Фондові матеріали Департамента екології та природних ресурсів Одеської обласної державної адміністраиії [Текст]: Результати гідрохімічних досліджень стану поверхневих вод в водних об єктах Одеської області в 2008-2017 pp. - 14 c. 
ВІСНИК

ОДЕСЬКОГО НАЦІОНАЛЬНОГО

МОРСЬКОГО УНІВЕРСИТЕТУ

№ 2 (59), 2019
HERALD

OF THE ODESSA

NATIONAL MARITIME UNIVERSITY

4. Сдине міжвідомче керівництво по організаиії та здійсненню державного моніторингу вод [Текст] K.: Мінекоресурсів України, 2001. $55 \mathrm{c}$.

5. Швеиь B.I. Вплив поверхнево-активних речовин на організм людини [Електронний ресурс] / B.I. Швеиьь, I.P. Тимофійчук, С.Б. Семененко, Н.В. Швецьь. Буковинський державний медичний університет, Чернівці. Клінічна та експериментальна патологія. 2017. Т.16, №2 (60) С 115-119. Режим доступу : https://www.bsmu.edu.ua ISSN 1727-4338

6. Мудрий І.В. Токсикологічне дослідження синтетичних миючих засобів на основі поверхнево-активних речовин [Електронний ресурс] І.В. Мудрий, В.Д. Чміль / інститут екогігієни і токсикол. ім. Л.І. Медведя. Украӥнський журнал сучасних проблем токсикології. - К.: 2000, № 4 Режим доступy: http://medved. kiev.ualarhiv_mg/st_2000/00_4_7.htm

7. Остроумов С.А. Влияние синтетических проверхностноактивных веществ на гидробиологические механизмы самоочищения водной среды [Електронный ресурс] С.А. Остроумов // Водные ресурсы 2004, т. 31. № 5. С. 546-555. Режим docmyny:https://www.researchgate.net/publication/295546994

8. Цитотоксична дія як критерій оиінки ступеня токсичності поверхнево активних речовин / O.I. Волощенко та ін. Гігієна населених місиь. 2012. Bun. 60. С. 174.

9. Герасімова В. Токсиколого-гігієнічна характеристика сучасних засобів для прання дитячої білизни та одягу. Український журнал сучасних проблем токсикології 2012, № 3-4 C 58-59 К.: [Електронний ресурс] Режим доступy: http://protox. medved.kiev.ua/index.php/ua/categories/mechanisms-of-intoxica-tions/ item/ 9-contemporary-baby-laundry-detergents-toxico-hygie-nic.

10. Проданчук М.Г. Сучасний стан токсиколого-гігієнічної оцінки поверхнево-активних речовин (огляд літератури). М.Г. Проданчук, І.В. Мудрий, О.В. Гудзь, А.А. Калашніков Інститут екогігієни і токсикології ім. Л.І. Медведя, Современные проблемы токсикологии №2. 2006. С 23-28.

11. Питна вода запорука екологічної безпеки регіону / Р.В. Пономаренко, Ю.В. Буи. Національний університет иивільного захисту України. Людина та довкілля. Проблеми неоекології. № 1-2, 2014. - С112-115. [Електронний ресурс] Режим досmyny: 36169-68325-1-SM.pdf.

12. Санитарные правила и нормы охраны поверхностных вод от загрязнения. [Текст]: СаНПиН № 4630-88. М.: Минздрав СССР. 1988. $69 \mathrm{c}$. 
13. Методика екологічної оцінки якості поверхневих вод за відповідними категоріями [Текст] / [Романенко В.Д., Жукинский В.М., Оксиюк О.П. та ін.]. К.: Символ-Т, 1999. 28 с.

\section{REFERENCES}

1. Xilchevskyi V.K., Osadchyi V.I., Kurylo S.M. (2012) Osnovy hidroximiyi [Fundamentals of hydrochemistry] Kyiv: Nika-Tsentr. (in Ukrainian)

2. Xromysheva O.O. (2008) Vyluchennia ionohennyx poverxnevoaktyvnyx rechovyn iz vodnyx rozchyniv metodom osadzhuvalnoi ta sorbtsiinoi mikroflotatsii [Extraction of ionic surfactans from aqueous solutions by precipitation and sorption microflotation method] Kyiv: NANU: avtoref. dys. kand. ximich. nauk p. 29. Available at: https:// studfiles. net/ preview/8172177 (in Ukrai-nian).

3. Fondovi materialy Departamenta ekolohii ta pryrodnyx resursiv Odeskoi oblasnoi derzhavnoi administratsii (2017) Rezultaty hidroximichnyx doslidzhen stanu poverxnevyx vod $v$ vodnyx obiektax Odeskoi oblasti v 2008-2017 y.y.[Results of hydrochemical studies of surface water status in water bodies of the Odessa region in 2008-2017], p. 14 (in Ukrainian)

4. Yedyne mizhvidomcha kerivnysttvo po organizatsii ta zdiysnenniu derzhavnoho monitorynhu vod (2001) [The only interagency guidance on the organization and implementation of state water monitoring] Kyiv: Minekoresursiv Ukrainy (in Ukrainian).

5. Shvets V.I., Tymofiychuk I.R., Semenenko S.B., Shvets N.V. (2017) Vplyv poverkhnevo-aktyvnykh rechovyn na orhanizm lyudyny [The influence of surfactants on the human body] Klinichna ta experymentalna patalohiia [Clinical and experimental pathology] (electronic journal), vol. 2 no.60, pp.115-119. Available at: https:// www.bsmu.edu.ua ISSN 1727-4338

6. Mudryi I.V.(2000)Toksykholohichne doslidzhennia syntetychnykh myiuchykh zasobiv na osnovi poverkhnevo-aktyvnyrh rechovyn [Toxic research on synthetic detergents based on surfactants] Ukrainskyi zhurnal suchasnykh problem toksykolohii [Ukrainian Journal of Contemporary ToxicologyProblems] no.4. Available at: http://medved.kiev.ua/arhiv_mg/st_2000/00_4_7.htm.

7. Ostroumov S.A.(2004) Viianie synteticheskykh poverkhnosno-aktivnykh veshchestv na hidrobiolohicheskie mekhanizmy samoochishcheniya vodnoy sredy [The effect of synthetic surfactants on the hydrobiological mechanisms of self-purification of the aquatic environment] Vodnye resursy(electronic jornal), vol. 31, no. 5, pp.546-555. Available at: https://www.researchgate. net/publication/295546994 
8. Voloshchenko O.I. (2012) Tsytotoksychna diia yak kryterii otsinky stupenia toksychnosti poverkhnevo aktyvnykh rechovyn [Cytotocxic action as a criterion for evaluating the degree of surfactants] Gihiena naselenykh mists [Hygiene of settlements] vol. 60, p.174.

9. Gerasimova V.(2012) Toksykoloho-hihienichna kharakterystyka suchasnykh zasobiv dlia prannia dytiachoii bilyzny ta odiahu [Toxicological-hygienic characteristics of modern detergents for children's underwear and clothing]. Kyiv. Ukrainskyy zhurnal suchasnykh problem toksykolohii [Ukrainian Journal of Contemporary ToxicologyProblems] no. 3-4 pp.58-59. Available at: http://protox.medved.kiev.ua/index.php/ua/categories/mechanismsof-intoxca-tions/item/9-contemporary-baby-laundry-detergentstoxico-hygienic.

10. Prodanchuk M.H., Mudryi I.V., Gudz O.V.,Kalashnikov A.A.(2006) Suchasnyi stan toksykoloho-hihienichnji otsinky poverkhnevo aktyvnykh rechovyn(ohliad literatury) [Current state of toxicological-hygienic evaluation of surfactants] Sovremennye problemy toksikolohii [Current problems of toxicology] no.2, pp.23-28

11. Ponomarenko P.V., Buts Yu.V.(2014) Pytna voda zaporuka ekolohichnoi bezpeky rehionu [Drinkin water is the key to the region's environmental security] Natsionalnyi universytet tsyvilnoho zakhystu Ukrainy. Liudyna ta dovkillia. Problemy neoekolohii (electronic journal), no.1-2, pp.112-115. Available at: 36169-68325-1SM.pdf.

12. Sanitarnye pravila I normy okhrany poverkhnostnykh vod ot zahrazneniia [Sanitary rules and norms of protection of surface waters from pollution] (1988). Moscow: Minzdrav SSSR, no.463088, p. 69.

13. Romanenko V.D., Zhukynckyi V.M., Oksyiuk O.P. (1999) Metodyka ekolohichnoi otsinky yakosti poverkhnevykh vod za vidpovidnymy katehoriiamy [Methodology for ecological assessment of surface water quality by relevant categories].Kyiv: Symvol-T, p. 28.

Стаття надійшла до редакиії 20.11.2019

\section{Рецензенти:}

доктор технічних наук, професор, професор кафедри Гідротехнічне будівництво Одеської державної академії будівництва та архітектури С.I. Рогачко

кандидат технічних наук, директор інституту Гідротехнічне будівництво та цивільна інженерія Одеської державної академії будівництва та архітектури В.Ф. Ісаєв 